\title{
Development and Evaluation of Taste Masked Granular Formulation of Satranidazole by Melt Granulation Technique
}

\author{
Harshal Ashok Pawar ${ }^{1}$ and Pooja Rasiklal Joshi ${ }^{2}$ \\ ${ }^{1}$ Department of Quality Assurance, Dr. L. H. Hiranandani College of Pharmacy, Smt. CHM Campus, \\ Opp. Ulhasnagar Railway Station, Ulhasnagar, Maharashtra 421003, India \\ ${ }^{2}$ Dr. L. H. Hiranandani College of Pharmacy, Ulhasnagar, Maharashtra 421003, India
}

Correspondence should be addressed to Harshal Ashok Pawar; harshal.dlhhcop@gmail.com

Received 15 November 2013; Accepted 31 December 2013; Published 12 February 2014

Academic Editor: Barbara R. Conway

Copyright (C) 2014 H. A. Pawar and P. R. Joshi. This is an open access article distributed under the Creative Commons Attribution License, which permits unrestricted use, distribution, and reproduction in any medium, provided the original work is properly cited.

Drugs from nitroimidazole category are generally bitter in taste. Oral formulation with bitter taste is not palatable. Geriatrics and pediatrics patients usually suffer from swallowing difficulties. Many other patients in some disease conditions avoid swallowing tablets. Satranidazole is a new nitro-imidazole derivative with bitter taste and is available in market as film coated tablet. The purpose of this research was to mask the bitter taste of Satranidazole by coating complexation with low melting point wax and Eudragit EPO. Different types of wax (glyceryl monostearate, stearic acid and cetyl alcohol) were tried for taste masking. The drug to stearic acid ratio 1:2 was found to be optimum on the basis of taste evaluation and in vitro release. The formulated granules were found to possess good flow property. FTIR studies confirmed that there was no interaction between drug and excipients. Scanning Electron Microscopy of drug and the optimized batch of granules was performed. The in vitro release of drug from granules was compared with marketed tablet formulation. The taste masked granules of optimized batch showed $87.65 \%$ release of drug in $1 \mathrm{hr}$ which is comparable to that of marketed tablet formulation.

\section{Introduction}

Masking the bitter taste of drugs is a challenge in development of all oral formulations and a necessity to ensure better patient compliance and product value where the process and formulation should be economic, rapid, and easy, involving least number of equipment, and processing steps and minimum number of excipients without adverse effect on drug bioavailability [1]. Bitter taste of drugs is a major problem in pediatric and geriatric formulations. Numerous methods are employed for effective taste masking, for example, use of flavors and sweeteners, microencapsulation, complexing with ion exchange resin, use of insoluble prodrug, formation of inclusion complexes, gelation, liposome, multiple emulsions, granulation, and so forth.

Taste masking can also be carried out using melt granulation technique [2]. Melt granulation is a process by which pharmaceutical powders are efficiently agglomerated by the use of a binder which can be a molten liquid or a solid that melts during the process. Different types of low melting point wax like glyceryl monostearate, palmitic acid, myristic acid, and so forth can also be used for taste masking as they form dense coating. Eudragit E100 is utilized along with low melting point waxes for dissolving it and spray cooled and granulated in a spray drying apparatus to obtain dense coating whereas if Eudragit E100 when dissolved in organic solvent forms porous coating which is difficult to mask the unpleasant taste [3].

Satranidazole (STZ) is a new nitroimidazole derivative with potent antiamoebic action. It is used in the treatment of intestinal and hepatic amoebiasis, giardiasis, trichomoniasis, and anaerobic infections. Its dose is $300 \mathrm{mg}$ twice daily for 3-5 days in the treatment of amoebiasis and $600 \mathrm{mg}$ as a single dose in the treatment of giardiasis and trichomoniasis. It is reported that Satranidazole exhibits significantly higher plasma concentrations than metronidazole and has a plasma elimination half-life of 1.01 hour which is significantly shorter than the corresponding metronidazole half-life of 3.62 hour 
[4]. Also, Satranidazole is having better tolerability, absence of neurological, and disulfiram-like reactions and it can be preferred in patients with susceptible neurological symptoms [5].

The present study aims for the development, optimization and evaluation of Satranidazole taste masked granular formulation using different types of low melting point wax with Eudragit EPO as a functional polymer by melt granulation technique.

\section{Materials and Methods}

2.1. Materials. Satranidazole was obtained as a gift sample from Alkem Laboratories, Mumbai. Eudragit EPO was obtained from Evonik Degussa, Mumbai. Satrogyl tablets (strength: $300 \mathrm{mg}$ ) were purchased from local market. All the chemicals and reagents used were of analytical grade.

2.2. Preformulation Studies. UV and FTIR spectrum of Satranidazole were taken to confirm the identity of drug. Compatibility study between the drug and the excipients was done using FTIR. IR spectra were recorded in Fourier Transform Infrared spectrophotometer (Shimadzu Corporation) with $\mathrm{KBr}$ pellets.

\subsection{Development and Optimization of Granular Formulation.} In preliminary study, three different trial batches of granules were prepared using glyceryl monostearate, stearic acid, and cetyl alcohol. The purpose of these trials was to select the wax suitable for taste masking of Satranidazole in low concentration since the dose of the drug is high. The required quantity of wax was weighed and melted in porcelain dish. Eudragit EPO was dissolved in molten wax and drug was added followed by mixing. At slightly lower temperature all the other ingredients were added and mixed. Finally the mixture was allowed to cool slightly and the solidified mass was passed through 12 \# sieve and then through 16 \#. The granules obtained were then lubricated with flavorant, sweetener and lubricant. The composition of granules is shown in Table 1.

Different batches of granules were prepared using wax selected in above trials to optimize drug to ratio for successful taste masking of STZ. The composition of the formulated batches is as shown in Table 2 .

2.4. Evaluation of Granules. The prepared batches were evaluated for the following parameters.

2.4.1. Flow Properties. The granules were evaluated for following flow properties using following parameters $[6,7]$.

2.4.2. Angle of Repose. Fixed funnel method was used to determine angle of repose and was calculated using following equation:

$$
\tan \theta=\frac{h}{r}
$$

where $h$ is height and $r$ is radius.
2.4.3. Bulk Density and Tapped Density. To measure density, the granules were filled in a $100 \mathrm{~mL}$ capacity measuring cylinder up to at least 3/4th the height. Bulk density is the quotient of weight to the volume of the sample. Tapped density is the quotient of weight of the sample to the volume after taping a measuring cylinder 500 times from a height of $\sim 1.5$ in.

2.4.4. Hausner Ratio and Carr's Index. Hausner's ratio was calculated using the following formula:

$$
\text { Hausner's Ratio }=\frac{\text { Tapped Density }}{\text { Bulk Density }} .
$$

The percentage compressibility (Carr's index) was calculated as 100 times the ratio of the difference between tapped density and bulk density to the tapped density:

$$
\text { Carr's index }=\frac{(\text { Tapped Density }- \text { Bulk Density })}{\text { Tapped Density }} \times 100 \text {. }
$$

2.4.5. Granular Friability. Ten grams of uncoated granules was subjected to friabilator at $25 \mathrm{rpm}$. After 4 minutes, the granules were sieved on a 200 mesh. The amount of granules passed through 200 mesh was calculated as percentage granular friability.

2.4.6. Particle Size Distribution. Particle size distribution was performed on optimized batch using nest of standard sieves (20 \#, 40 \#, 60 \#, 100 \#, and 120 \#). The sieves were agitated mechanically for 10 minutes on a sieve shaker and the weight of granules retained on each smaller sieve was noted.

2.4.7. Scanning Electron Microscopy (SEM). The surface morphology of uncoated and coated granules was examined using a scanning electron microscope (Zeiss Ultra Plus-FESEM). The samples of granules were previously sputter-coated with gold.

2.4.8. In Vitro Dissolution Studies in 0.1N Hydrochloric Acid ( $\mathrm{HCl})$. In vitro dissolution studies were carried out using USP II Apparatus (Paddle Method) rotating at $75 \mathrm{rpm}$ in $900 \mathrm{~mL}$ of $0.1 \mathrm{~N} \mathrm{HCl}$ as dissolution media maintained at $37 \pm 0.5^{\circ} \mathrm{C}$. Sampling was done at different time intervals of $10,15,30,45$, and 60 minutes by withdrawing $5 \mathrm{~mL}$ of the dissolution medium and replacing it with the same amount of medium to maintain sink conditions. The withdrawn samples were filtered and the contents of sample were determined spectrophotometrically at $320 \mathrm{~nm}$. The dissolution of marketed tablet formulation (Satrogyl Tablet, $300 \mathrm{mg}$ ) was also carried using the similar dissolution conditions. The Percent cumulative release of drug was calculated using standard calibration curve of STZ prepared in $0.1 \mathrm{~N} \mathrm{HCl}$.

2.4.9. Determination of Drug Content (Percent Assay) Using HPLC. The assay of different batches of granules of Satranidazole with stearic acid was carried out using previously developed and validated HPLC method. Isocratic elution at a flow rate of $1.0 \mathrm{~mL} / \mathrm{min}$ was employed on BDS Hypersil C18 
TABLE 1: Composition of preliminary trial batches.

\begin{tabular}{|c|c|c|c|c|}
\hline \multirow{3}{*}{ Ingredients } & \multicolumn{3}{|c|}{ Batches } & \multirow{3}{*}{ Role } \\
\hline & Trial 1 & Trial 2 & Trial 3 & \\
\hline & \multicolumn{3}{|c|}{ Quantity in mg per dose } & \\
\hline Satranidazole & 300 & 300 & 300 & Active ingredient \\
\hline Glyceryl monostearate & 600 & - & - & Low melting point wax \\
\hline Cetyl alcohol & - & - & 600 & Low melting point wax \\
\hline Stearic acid & - & 600 & - & Low melting point wax \\
\hline Eudragit EPO & 100 & 100 & 100 & Functional polymer \\
\hline Starch 1500 & 200 & 200 & 200 & Disintegrant \\
\hline Magnesium oxide & 70 & 70 & 70 & Additive for taste masking \\
\hline Mannitol & 498 & 498 & 498 & Diluent \\
\hline Xylitol & 42 & 42 & 42 & Sweetener \\
\hline $\begin{array}{l}\text { Sodium carboxymethyl cellulose } \\
\text { (sodium CMC) }\end{array}$ & 20 & 20 & 20 & Disintegrant \\
\hline $\begin{array}{l}\text { Hydroxyllpropyl cellulose } \\
\text { (low substituted) HPC }\end{array}$ & 80 & 80 & 80 & Disintegrant \\
\hline Vanilla & 20 & 20 & 20 & Flavorant \\
\hline Aspartame & 65 & 65 & 65 & Sweetener \\
\hline Magnesium stearate & 5 & 5 & 5 & Lubricant \\
\hline In vitro taste evaluation by $\mathrm{UV}(\mu \mathrm{g} / \mathrm{mL})$ & 37.81 & 23.33 & 33.14 & - \\
\hline
\end{tabular}

* All the batches showed less than threshold value in in vitro taste evaluation by UV.

TABLE 2: Composition of batches prepared using selected wax for optimization.

\begin{tabular}{|c|c|c|c|c|}
\hline \multirow{4}{*}{ Ingredients } & $\mathrm{F} 1$ & F2 & F3 & $\mathrm{F} 4$ \\
\hline & \multicolumn{4}{|c|}{ Ratio of drug : stearic acid } \\
\hline & $1: 1$ & $1: 1.5$ & $1: 2$ & $1: 2.5$ \\
\hline & \multicolumn{4}{|c|}{ Quantity in mg per dose } \\
\hline Satranidazole & 300 & 300 & 300 & 300 \\
\hline Stearic acid & 300 & 450 & 600 & 750 \\
\hline Eudragit EPO & 100 & 100 & 100 & 100 \\
\hline Starch 1500 & 200 & 200 & 200 & 200 \\
\hline Magnesium oxide & 70 & 70 & 70 & 70 \\
\hline Mannitol & 798 & 648 & 498 & 348 \\
\hline Xylitol & 42 & 42 & 42 & 42 \\
\hline Sodium CMC & 20 & 20 & 20 & 20 \\
\hline HPC & 80 & 80 & 80 & 80 \\
\hline Vanilla & 20 & 20 & 20 & 20 \\
\hline Aspartame & 65 & 65 & 65 & 65 \\
\hline Magnesium stearate & 5 & 5 & 5 & 5 \\
\hline
\end{tabular}

$(250 \mathrm{~mm} \times 4.6 \mathrm{~mm}, 5 \mu \mathrm{m})$ column at $25^{\circ} \mathrm{C}$ temperature. The mobile phase consisting of $0.16 \% \mathrm{v} / \mathrm{v}$ orthophosphoric acid solution, $\mathrm{pH} \mathrm{3}$, and acetonitrile in the ratio of $60: 40 \mathrm{v} / \mathrm{v}$ was used. The UV detection wavelength was $320 \mathrm{~nm}$, and $20 \mu \mathrm{L}$ sample was injected. Standard stock solution was prepared by dissolving $50 \mathrm{mg}$ of Satranidazole in $50 \mathrm{~mL}$ methanol and was further diluted with mobile phase to obtain standard solution of $40 \mu \mathrm{g} / \mathrm{mL}$ concentration. The sample solution was prepared by adding granules equivalent to $20 \mathrm{mg}$ of Satranidazole in methanol. The dispersion was sonicated for $30 \mathrm{~min}$ and was then filtered. The resultant solution was further diluted with mobile phase to get $40 \mu \mathrm{g} / \mathrm{mL}$ of test solution. The solutions were filtered through $0.45 \mu$ nylon filter. Equal volumes of sample preparation and standard preparation were injected separately into the HPLC (an agilent high performance liquid chromatograph equipped with quaternary pump) and chromatograms were recorded.

\subsection{Taste Masking Evaluation}

2.5.1. Determination of Bitter Taste Recognition Threshold of Satranidazole. Threshold value of STZ was determined based on the bitter taste recognized by eight volunteers in the age group of 21-28 years. Aqueous solutions of STZ with different 
concentrations $(10,20,30$, and $40 \mu \mathrm{g} / \mathrm{mL})$ were prepared. One milliliter of solution was placed on the center of the tongue of volunteer for 30 seconds. The solution was spat out after 30 seconds, and the mouth was thoroughly rinsed with distilled water. The same procedure was repeated for all solutions and volunteers. A gap of 30 minutes was maintained in between tasting two different solutions. The same procedure was repeated for STZ solutions with concentrations 24, 26, 28,32 , and $35 \mu \mathrm{g} / \mathrm{mL}$. The threshold value was selected on the basis of the lowest concentration that had a bitter taste [8-10].

2.5.2. In Vitro Evaluation of Bitter Taste of Granules. Granules equivalent to $25 \mathrm{mg}$ of STZ were placed in a volumetric flask with $50 \mathrm{~mL}$ of phosphate buffer ( $\mathrm{pH}$ 6.8) and stirred for 5 minutes. The mixture was filtered, and the filtrate was analyzed for STZ concentration at $320 \mathrm{~nm}$ by UV-Visible spectrophotometer and that was compared with the threshold value [11].

2.5.3. In Vivo Taste Evaluation. Two procedures were used for in vivo taste evaluation.

(1) Gustatory sensation taste: informed consent was first obtained from 8 healthy volunteers and taste evaluation study was carried out. The whole dose was added to $100 \mathrm{~mL}$ of water for 15 seconds. STZ was used as control. After 15 seconds, $1 \mathrm{~mL}$ of dispersion was held in the mouth of each volunteer for 30 seconds and then spat out [8]. The bitterness level was recorded by using the numerical scale shown in Table 3.

(2) Granules equivalent to $50 \mathrm{mg} \mathrm{STZ}$ were held in mouth of each volunteer for 30 seconds. After expectoration, bitterness level was recorded by using the numerical scale shown in Table 3.

2.6. Stability Studies. The optimized granular formulation was subjected for stability study for one month according to ICH guidelines. Tests were conducted at room temperature (RT) and accelerated stability conditions. The samples were designated as time 0 and 1 month for RT and 0 and 1 month for accelerated studies. Samples designed for RT storage were kept at $25 \pm 2^{\circ} \mathrm{C}$ and $60 \pm 5 \%$ relative humidity $(\mathrm{RH})$. The samples in the accelerated stability study were kept at $40 \pm 2^{\circ} \mathrm{C}$ and $75 \pm 5 \%$ RH in humidity chamber. Samples were tested for its appearance, flow properties, taste masking, in vitro release, and drug content using the previously described procedures.

\section{Results and Discussion}

The UV spectrum of STZ in methanol is shown in Figure 1. The $\lambda$ max of Satranidazole sample was found to be $320 \mathrm{~nm}$. STZ exhibited characteristic peaks at 1687, 1743, 1066, 1537, and $1215 \mathrm{~cm}^{-1}$ attributed to $\mathrm{C}=\mathrm{N}$ stretching, $\mathrm{C}=\mathrm{O}$ stretching, $\mathrm{S}=\mathrm{O}$ stretching, $\mathrm{C}-\mathrm{NO}_{2}$ stretching, and $\mathrm{C}-\mathrm{N}$ vibrations. FTIR spectra showed all the important peaks of drug in spectra of drug-excipient mixture and formulation. FTIR of STZ, physical mixture of STZ with Eudragit EPO and stearic
TABLE 3: Numerical scale for bitterness level.

\begin{tabular}{lc}
\hline Score & Inference \\
\hline 0 & Pleasant \\
1 & Tasteless \\
2 & Slightly bitter \\
3 & Moderately bitter \\
4 & Extremely bitter \\
\hline
\end{tabular}

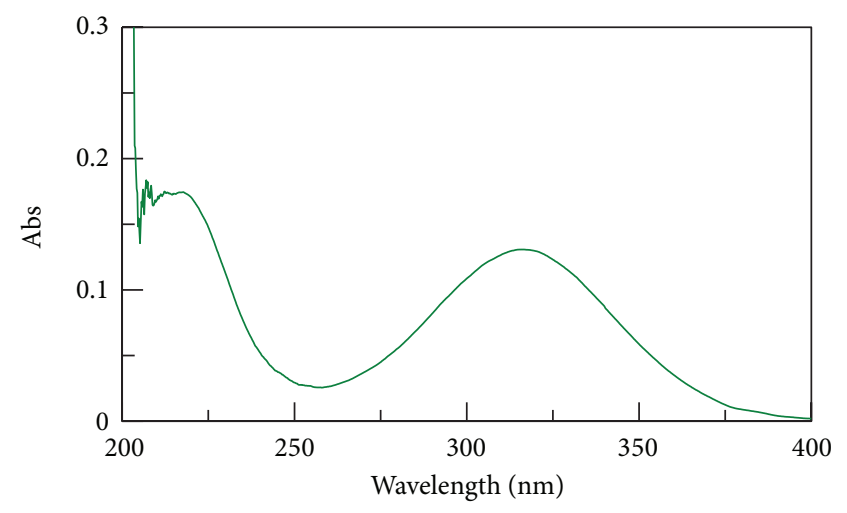

FIGURE 1: UV spectrum of STZ in methanol.

acid, and the optimized formulation is represented in Figures $2,3,4$, and 5 , respectively.

All the excipients were selected based on preformulation study results and extensive literature survey. Low melting point wax was used to form dense coating around the drug particle to mask the taste. Eudragit EPO was used as a functional polymer which is insoluble above $\mathrm{pH} 5$ and thus prevents release of STZ in mouth. Preliminary trials were taken for the selection of wax. The ratio of the drug to wax was selected based on literature survey $[2,3]$. Initially, three different granular formulations were prepared using three different types of wax (glyceryl monostearate, stearic acid, and cetyl alcohol) individually in drug to wax ratio $1: 2$. In preliminary trials, it was found that granules of STZ formed with stearic acid (Trial 2) were better taste masked. The granules formed with glyceryl monostearate and cetyl alcohol in the same ratio with drug were bitter in taste. Hence, the ratio of STZ to stearic acid was varied from $1: 1$ to $1: 2.5$ in further optimization and formed batches were evaluated for taste masking and other parameters such as flow property, drug content (assay), and in vitro drug release.

The results of bulk density, tapped density, Carr's index, Hausner ratio, and angle of repose are summarized in Table 4. The results indicated that the prepared granules possess good flow property [12].

The taste recognition threshold of STZ was determined on the basis of Table 5. The threshold was found to be $28 \mu \mathrm{g} / \mathrm{mL}$.

Under in vitro taste masking evaluation study, the drug release in $\mathrm{pH} 6.8$ phosphate buffer was studied. It was observed that the granules formed with glyceryl monostearate were showing more release than threshold concentration in 6.8 phosphate buffer and were less hard and the granules formed with cetyl alcohol were found to be very 
TABLE 4: Results of flow evaluation.

\begin{tabular}{lcccc}
\hline Parameters & F1 & F2 & F3 & F4 \\
\hline Bulk density $\left(\mathrm{gm} / \mathrm{cm}^{3}\right)$ & $0.50 \pm 0.028$ & $0.50 \pm 0.031$ & $0.52 \pm 0.031$ & $0.53 \pm 0.021$ \\
Tapped density $\left(\mathrm{gm} / \mathrm{cm}^{3}\right)$ & $0.57 \pm 0.026$ & $0.56 \pm 0.015$ & $0.58 \pm 0.013$ & $0.60 \pm 0.023$ \\
Carr's compressibility index $(\%)$ & $12.281 \pm 0.075$ & $12 \pm 0.102$ & $10.345 \pm 0.081$ & $11.667 \pm 0.098$ \\
Angle of repose $\left(^{\circ}\right)$ & $29.34 \pm 0.176$ & $25.61 \pm 0.081$ & $25.42 \pm 0.142$ & $27.33 \pm 0.133$ \\
Hausner ratio & $1.14 \pm 0.011$ & $1.12 \pm 0.009$ & $1.1153 \pm 0.01$ & $1.1320 \pm 0.01$ \\
\hline
\end{tabular}

${ }^{*}$ All above readings are average \pm standard deviation, $n=6$.

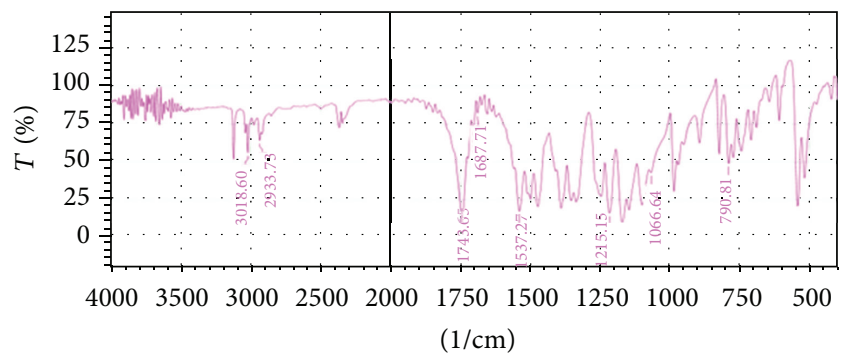

FIGURE 2: FTIR of STZ.

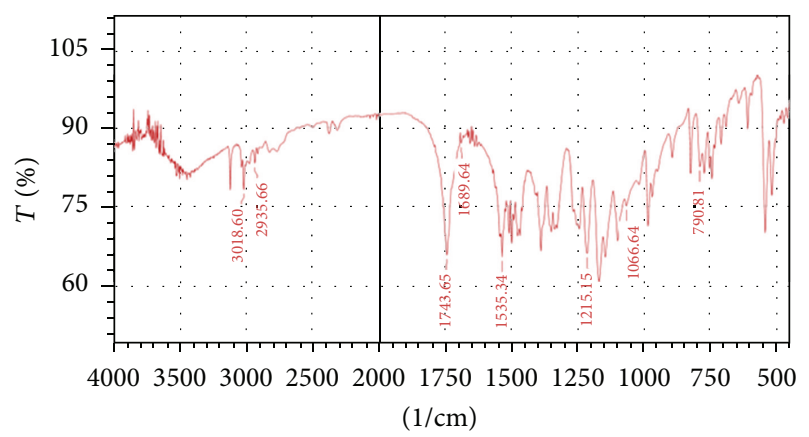

FIGURE 3: FTIR of drug with Eudragit EPO.

hard as cetyl alcohol used to quickly solidifies on melting and therefore the drug was not completely coated with it and showed more release than threshold concentration in 6.8 phosphate buffer.

Results of drug release from granules of batches F1 and F2 were found to be more than the threshold value, that is, $28 \mu \mathrm{g} / \mathrm{mL}$. The drug release from granules of batches F3 and F4 was found to be less than the threshold value which indicated successful taste masking of granules. Gustatory sensation test results obtained from 8 healthy volunteers also indicated that the granules of batches F3 and F4 were better taste masked. Table 6 indicates the in vivo and in vitro taste masking evaluation results of the granular formulations F1 to F4.

Typical HPLC chromatogram of test solution is represented in Figure 6. The STZ peak was eluted at the retention time of about 4.32 minutes. The percentage of drug content for different batches (F1-F4) was found to be in the range of 98-102\%.

The results of in vitro dissolution studies and drug content (assay) of different batches (F1-F4) are summarized in Table 7. It was found that as the amount of stearic acid increases in the granules and the \% drug release in $0.1 \mathrm{~N} \mathrm{HCl}$

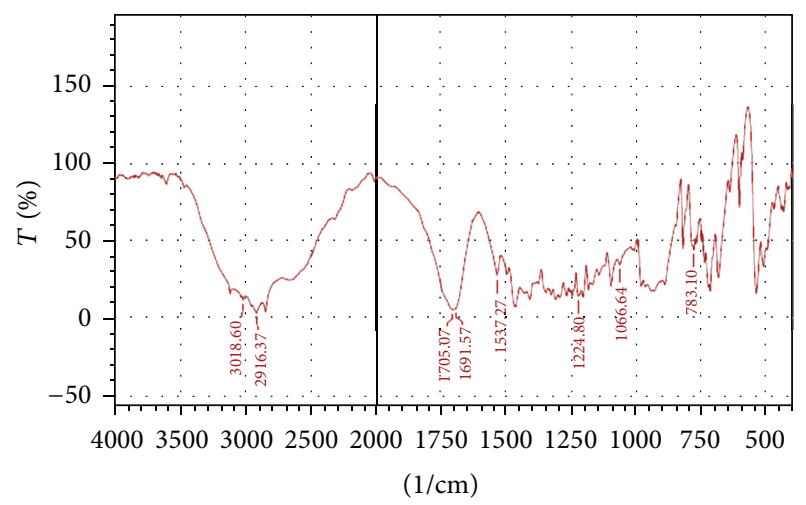

FIGURE 4: FTIR of STZ with Stearic acid.

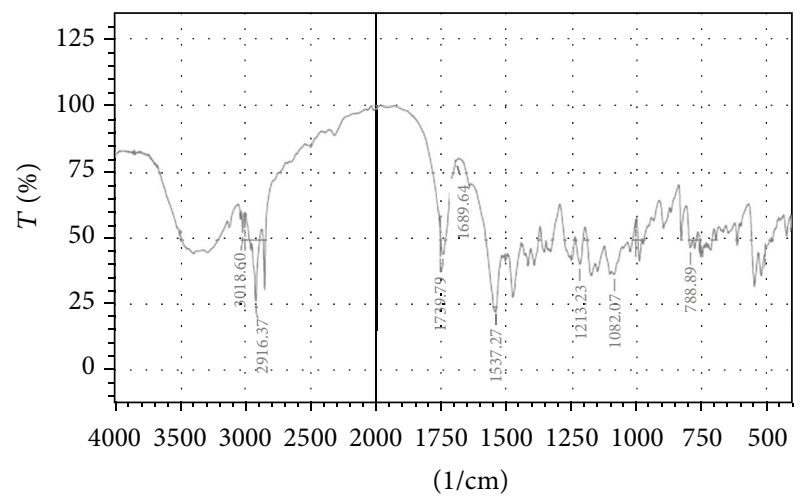

FIGURE 5: FTIR of optimized formulation (F3).

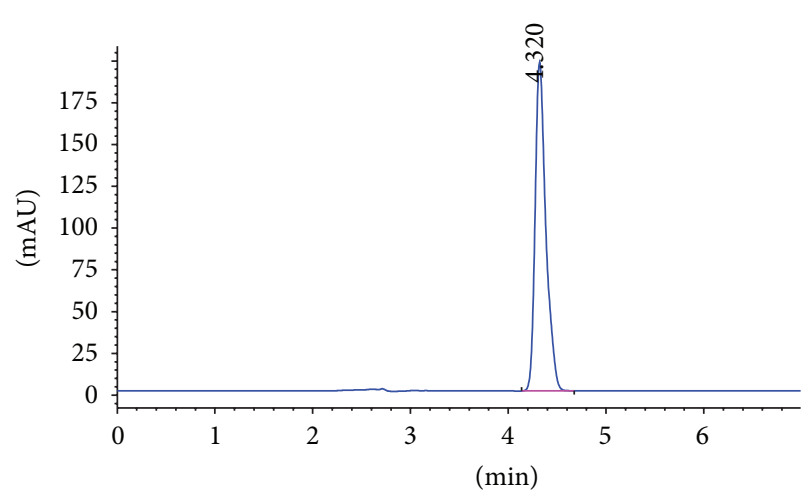

FIgURE 6: Typical chromatogram of test solution. 
TABLE 5: Taste recognition threshold determination.

\begin{tabular}{lcccccccc}
\hline $\begin{array}{c}\text { Concentration } \\
(\mu \mathrm{g} / \mathrm{mL})\end{array}$ & 1 & 2 & 3 & 4 & 5 & 6 & 7 & 8 \\
\hline 10 & $\mathrm{~N}$ & $\mathrm{~N}$ & $\mathrm{~N}$ & $\mathrm{~N}$ & $\mathrm{~N}$ & $\mathrm{~N}$ & $\mathrm{~N}$ & $\mathrm{~N}$ \\
20 & $\mathrm{~N}$ & $\mathrm{~N}$ & $\mathrm{~N}$ & $\mathrm{~N}$ & $\mathrm{~N}$ & $\mathrm{~N}$ & $\mathrm{~N}$ & $\mathrm{~N}$ \\
22 & $\mathrm{~N}$ & $\mathrm{~N}$ & $\mathrm{~N}$ & $\mathrm{~N}$ & $\mathrm{~N}$ & $\mathrm{~N}$ & $\mathrm{~N}$ & $\mathrm{~N}$ \\
24 & $\mathrm{~N}$ & $\mathrm{~N}$ & $\mathrm{~N}$ & $\mathrm{~N}$ & $\mathrm{~N}$ & $\mathrm{~N}$ & $\mathrm{~N}$ & $\mathrm{~N}$ \\
26 & $\mathrm{~N}$ & $\mathrm{~N}$ & $\mathrm{~N}$ & $\mathrm{~N}$ & $\mathrm{~N}$ & $\mathrm{~N}$ & $\mathrm{~N}$ & $\mathrm{~N}$ \\
28 & $\mathrm{~N}$ & $\mathrm{~N}$ & $\mathrm{~N}$ & $\mathrm{Y}$ & $\mathrm{N}$ & $\mathrm{Y}$ & $\mathrm{N}$ & $\mathrm{N}$ \\
30 & $\mathrm{Y}$ & $\mathrm{N}$ & $\mathrm{Y}$ & $\mathrm{N}$ & $\mathrm{Y}$ & $\mathrm{Y}$ & $\mathrm{Y}$ & $\mathrm{Y}$ \\
32 & $\mathrm{Y}$ & $\mathrm{Y}$ & $\mathrm{Y}$ & $\mathrm{Y}$ & $\mathrm{Y}$ & $\mathrm{Y}$ & $\mathrm{Y}$ & $\mathrm{Y}$ \\
35 & $\mathrm{Y}$ & $\mathrm{Y}$ & $\mathrm{Y}$ & $\mathrm{Y}$ & $\mathrm{Y}$ & $\mathrm{Y}$ & $\mathrm{Y}$ & $\mathrm{Y}$ \\
40 & $\mathrm{Y}$ & $\mathrm{Y}$ & $\mathrm{Y}$ & $\mathrm{Y}$ & $\mathrm{Y}$ & $\mathrm{Y}$ & $\mathrm{Y}$ & $\mathrm{Y}$ \\
\hline
\end{tabular}

${ }^{*} \mathrm{Y}$ : recognition of bitter taste; N: no perception of bitter taste.

TABLE 6: Results of in vivo and in vitro taste masking evaluation.

\begin{tabular}{lcc}
\hline Batch & $\begin{array}{c}\text { Taste masking score } \\
\text { by gustatory sensation } \\
\text { test }\end{array}$ & $\begin{array}{c}\text { In vitro release of STZ } \\
\text { by UV in } 5 \text { min } \\
(\mu \mathrm{g} / \mathrm{mL})\end{array}$ \\
\hline F1 & 3 & 32.01 \\
F2 & 2 & 30.97 \\
{$[-1 \mathrm{pt}] \mathrm{F} 3$} & 1 & 23.33 \\
F4 & 1 & 21.12 \\
\hline
\end{tabular}

decreases, the granular strength increases and the friability decreases. The batch F4 formulated with drug to stearic acid ratio $1: 2.5$ showed $76.87 \%$ release in $0.1 \mathrm{~N} \mathrm{HCl}$, whereas batch F3 showed almost $87.65 \%$ release of drug in $1 \mathrm{hr}$ which was almost same as that of the marketed tablet, that is, $88.1 \%$ release in $1 \mathrm{hr}$. The formulated granules with drug to stearic acid ratio $1: 2$ showed better release in $0.1 \mathrm{~N} \mathrm{HCl}$ with complete taste masking. Hence, formulation F3 was considered as optimized formulation. Batch F3 was subjected to stability studies for one month as per ICH guidelines. The comparison of in vitro drug release from optimized formulation (F3) and marketed tablet in $0.1 \mathrm{~N} \mathrm{HCl}$ is shown in Figure 7.

The Granular friability of granules of optimized batch (F3) was found to be $0.15 \%$. The size of the granules was found in the range of $341.93 \mu \mathrm{m}-487.5 \mu \mathrm{m}$. SEM photographs of drug and granules are as shown in Figures 8 and 9, respectively. It was found that the surface of the drug particle was smooth and that of the granules was rough.

Stability study results indicated that there was no change in physical appearance of granules and taste at room temperature as well as accelerated conditions. The results of percent dissolution, assay, and flow properties of the optimized batch F3 at RT and accelerated stability conditions are summarized in Table 8. The optimized formulation was found stable during stability study.

\section{Conclusion}

Taste masking of bitter drugs with higher dose is challenging. STZ is having a dose of $300 \mathrm{mg}$ twice daily in amoebiasis

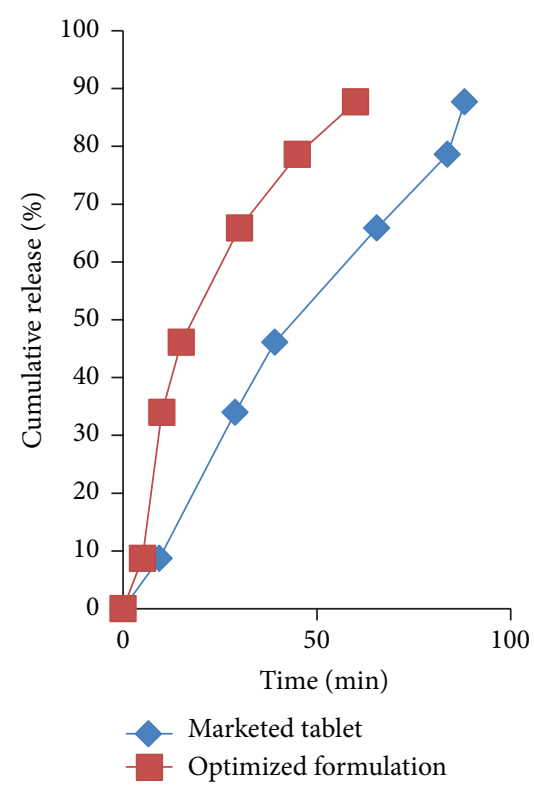

FIGURE 7: Comparison of in vitro dissolution study of optimized formulation and marketed tablet in $0.1 \mathrm{~N} \mathrm{HCl}$.

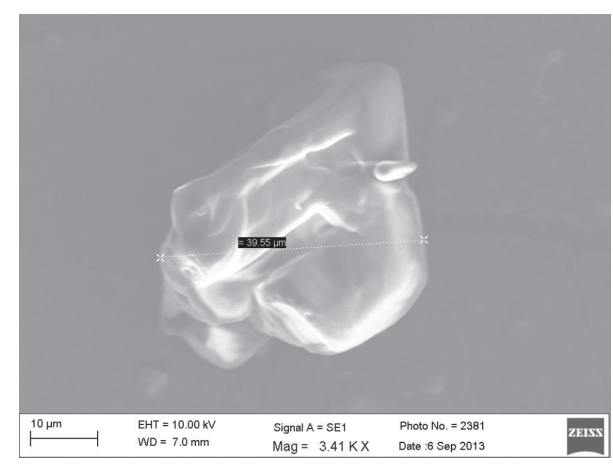

FIGURE 8: SEM image of drug particle.

and is available in market in the form of film coated tablet. Difficulty in swallowing tablets is a major problem especially in case of geriatrics and pediatrics as well as patients who are not able to swallow tablets. In the above technique, low melting point wax was used for dissolving Eudragit EPO instead of organic solvent which led to the formation of dense coating around the drug and also step of removal of organic solvent by carrying out drying step was not required by using wax. Granules formed by coating with Eudragit EPO showed similar release of STZ like that of marketed tablet. From the above results, it can be concluded that complete taste masking of bitter STZ is achieved by granulating drug with stearic acid and Eudragit E100 by melt granulation technique. The efficiency of stearic acid was tested for the purpose of taste masking with the possible method of melt granulation. Taste masking by the above technique is achieved by decreasing the surface area of the drug by increasing its particle size and the method was found to be very simple. 
TABLE 7: \% cumulative release and assay in 0.1 N HCL.

\begin{tabular}{lccccc}
\hline Time (minutes) & F1 & F2 & F3 & F4 & Marketed formulation \\
\hline 5 & $7.61 \pm 0.367$ & $8.02 \pm 0.512$ & $8.71 \pm 0.426$ & $5.31 \pm 0.378$ & $9.34 \pm 0.432$ \\
10 & $86.93 \pm 0.523$ & $52.99 \pm 0.69$ & $33.9 \pm 0.299$ & $25.71 \pm 0.362$ & $28.87 \pm 0.471$ \\
15 & $98.46 \pm 0.647$ & $62.68 \pm 0.489$ & $46.05 \pm 0.343$ & $36.12 \pm 0.298$ & $39.1 \pm 0.572$ \\
30 & $104.34 \pm 0.701$ & $73.40 \pm 0.397$ & $65.83 \pm 0.378$ & $58.54 \pm 0.452$ & $65.43 \pm 0.503$ \\
45 & $102.17 \pm 0.489$ & $81.66 \pm 0.434$ & $78.57 \pm 0.418$ & $71.27 \pm 0.514$ & $83.66 \pm 0.66$ \\
60 & $102.11 \pm 0.585$ & $90.01 \pm 0.546$ & $87.65 \pm 0.404$ & $76.87 \pm 0.539$ & $88.1 \pm 0.55$ \\
Assay (\%) & $100.87 \pm 0.465$ & $98.91 \pm 0.487$ & $99.69 \pm 0.574$ & $101.25 \pm 0.521$ & $97.89 \pm 0.464$ \\
\hline
\end{tabular}

${ }^{*}$ All above readings are average \pm standard deviation, $n=6$.

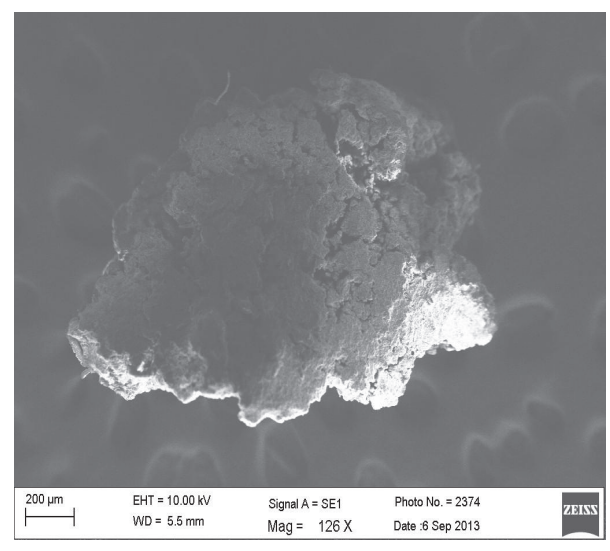

FIGURE 9: SEM image of optimized granular formulation (F3).

TABLE 8: Stability study results.

\begin{tabular}{lcccc}
\hline \multirow{2}{*}{ Parameters } & \multicolumn{2}{c}{ At RT } & \multicolumn{2}{c}{ At accelerated conditions } \\
& 0 month & 1 month & 0 month & 1 month \\
\hline $\begin{array}{l}\text { Assay (\%) } \\
\text { \% dissolution } \\
\text { (in 1 hr) }\end{array}$ & 98.94 & 98.75 & 98.87 & 98.62 \\
Flow property & Good & Good & Good & Good \\
\hline
\end{tabular}

\section{Conflict of Interests}

The authors declare that there is no conflict of interests regarding the publication of this paper.

\section{Acknowledgment}

The authors are very much thankful to Dr. P. S. Gide, Principal of Hyderabad Sindh National Collegiate Boards (HSNCBs), Dr. L. H. Hiranandani College of Pharmacy, Ulhasnagar, for his continuous support, guidance, and encouragement.

\section{References}

[1] A. Khames, A. Helmy, S. Kady, and A. Abd-elbary, "Preparation, characterization, and in-vitro/vivo evaluation of indion-based chewable tablets of paracetamol and ibuprofen for pediatric use," Journal of American Science, vol. 7, no. 12, pp. 831-844, 2011.
[2] S. B. Ahire, P. D. Gaikwad, V. H. Bankar, and S. P. Pawar, "Taste masking of metoclopramide hydrochloride by novel melt granulation," International Journal of Drug Delivery, vol. 4, pp. 89-94, 2012.

[3] T. Yajima, K. Ishii, N. Umeki et al., "Taste masking pharmaceutical composition," United States patent US005707646A, 1998.

[4] A. Pargal, C. Rao, K. K. Bhopale, K. S. Pradhan, K. B. Masani, and C. L. Kaul, "Comparative pharmacokinetics and amoebicidal activity of metronidazole and satranidazole in the golden hamster, Mesocricetus auratus," Journal of Antimicrobial Chemotherapy, vol. 32, no. 3, pp. 483-489, 1993.

[5] D. M. Parmar and S. P. Jadav, "The concept of personal drugs in the undergraduate pharmacology practical curriculum," Indian Journal of Pharmacology, vol. 39, no. 3, pp. 165-167, 2007.

[6] H. A. Pawar and P. M. D'mello, "Development and evaluation of herbal laxative granules," Journal of Chemical and Pharmaceutical Research, vol. 3, no. 3, pp. 646-650, 2011.

[7] K. S. Remya, P. Beena, P. V. Bijesh, and A. Sheeba, "Formulation development, evaluation and comparative study of effects of super disintegrants in cefixime oral disintegrating tablets," Journal of Young Pharmacists, vol. 2, no. 3, pp. 234-239, 2010.

[8] B. Albertini, C. Cavallari, N. Passerini et al., "Characterization and taste-masking evaluation of acetaminophen granules: comparison between different preparation methods in a high-shear mixer," European Journal of Pharmaceutical Sciences, vol. 21, no. 2-3, pp. 295-303, 2004.

[9] W. Chang, J. W. Chung, Y. Kim, S. Chung, and H. Kho, “The relationship between phenylthiocarbamide (PTC) and 6-npropylthiouracil (PROP) taster status and taste thresholds for sucrose and quinine," Archives of Oral Biology, vol. 51, no. 5, pp. 427-432, 2006.

[10] Y. Gao, F. Cui, Y. Guan, L. Yang, Y. Wang, and L. Zhang, "Preparation of roxithromycin-polymeric microspheres by the emulsion solvent diffusion method for taste masking," International Journal of Pharmaceutics, vol. 318, no. 1-2, pp. 62-69, 2006.

[11] D. Bora, P. Borude, and K. Bhise, "Taste masking by spraydrying technique," AAPS PharmSciTech, vol. 9, no. 4, pp. 11591164, 2008.

[12] M. Shaik, A. Arunachalam, A. M. S. Sudhakar, N. Vanitha, C. H. Koteswararao, and P. G. Bhavani, "Invention and in vitro evaluation of floating tablets of metformin hydrochloride using hydrophilic polymer as release retardant," International Journal of Biological and Pharmaceutical Research, vol. 3, no. 3, pp. 339346, 2012. 

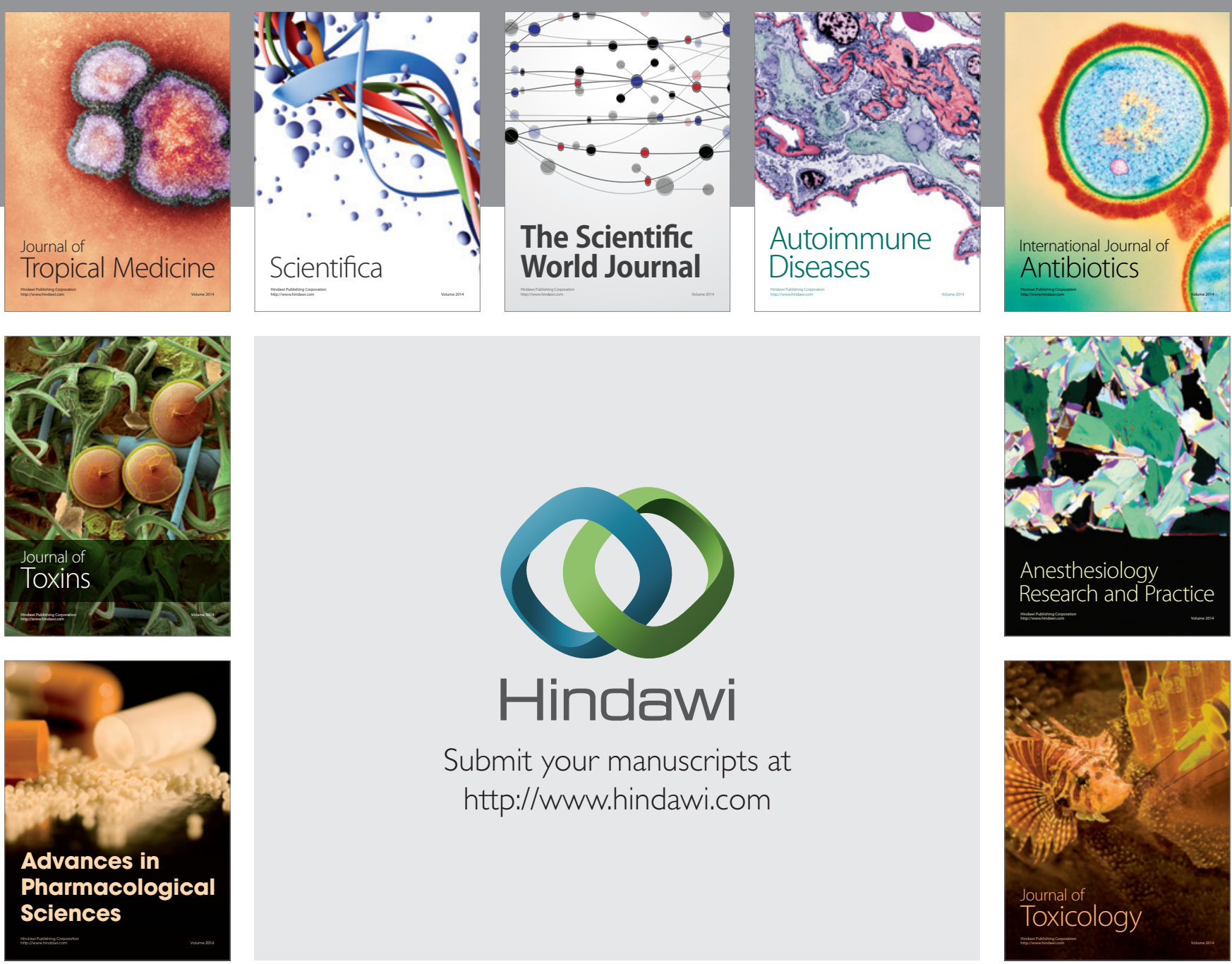

\section{Hindawi}

Submit your manuscripts at

http://www.hindawi.com
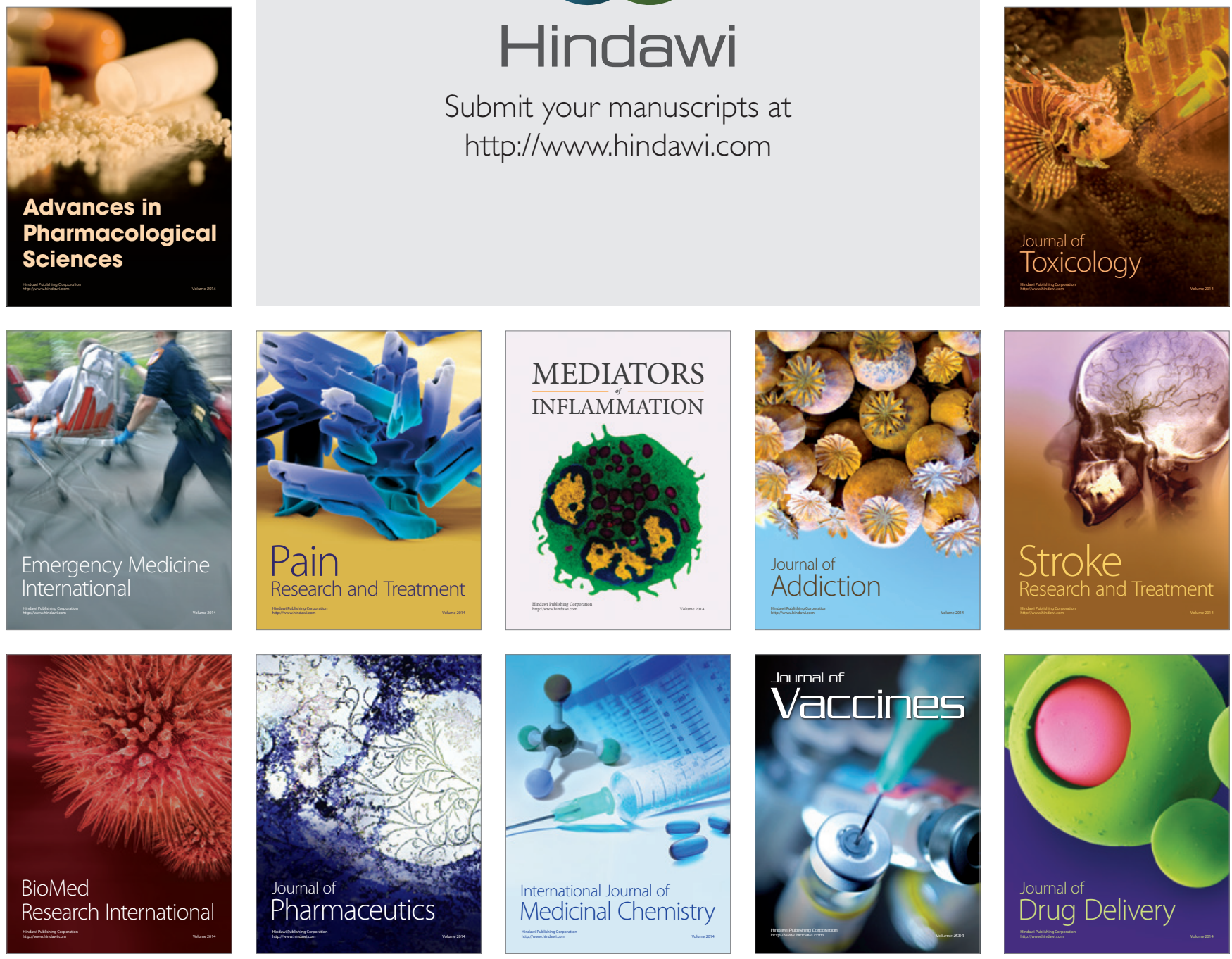